\title{
ANALISIS KORELASI KANONIK PERMINTAAN NON-FUNGSIONAL
}

\author{
Iskandar Putong \\ Management Department, School of Business Management, BINUS University \\ Jln. K. H. Syahdan No. 9, Palmerah, Jakarta Barat 11480 \\ putong304278@binus.ac.id
}

\begin{abstract}
Interdependency analysis (canonical correlation analysis) intends to determine how much influence among the variables comprising two groups of variables (set variable) reciprocal between demand variables non-functional group member to request a non-functional group non-member. By using a sample of 45 respondents which were valid and reliable, normally distributed, homogeneous, numeric and no autocorrelation, the resulting data consist of 2 groups (2 sets), each group consisting of three indicator variables (manifest) variables, namely Mode Effect(M1 and NM1), Prestige effect (M2 and nm2) and the Veblen effect (M3 and NM3) with the hypothesis that the variable demand affects Non-functional Member Non-Member. Data were analyzed with the model of canonical correlation and MANOVA statistical test at alpha level of 5\% (1 and 2-way), with the tools SPSS ver.21, showed that the effect of the variable group (based on eigenvalue) Member of the NonMember is larger than the effect of non-Member to Member in 2 of 3 Root generated. These results indicate that the effect of Mode, prestige, and Veblen affect to non-member and statistically significant.
\end{abstract}

Keywords: Interdependence Analysis, Canonical Correlation, Non-functional Demand, eigenvalue, root

\begin{abstract}
ABSTRAK
Analisis interdependensi (Analisis Korelasi Kanonikal) ditujukan untuk mengetahui seberapa besar pengaruh antara variabel yang terdiri atas 2 gugus variabel (set variable) yang bersifat timbal balik antara variabel permintaan non-fungsional Kelompok member terhadap permintaan non-fungsional kelompok nonmember. Dengan menggunakan sampel sebanyak 45 responden yang valid dan reliabel, berdistribusi normal,homogeny,numeric, dan tidak berotokorelasi, data yang dihasilkan terdiri atas 2 gugus (2 set) yang masing-masing gugus terdiri atas 3 variabel indikator (manifest) yaitu variabel Efek Mode (M1 dan NM1), efek Gengsi (M2 dan NM2), dan efek Pamer (M3 dan NM3) dengan hipotesis penelitian bahwa variabel permintaan Non-fungsional Member berpengaruh terhadap Non-member. Data dianalisis dengan model Korelasi Kanonik dan uji statistik MANOVA pada taraf alpha 5\% (1 dan 2 arah), dengan bantuan SPSS ver.21, menunjukkan bahwa pengaruh gugus variabel (berdasarkan nilai Eigenvalue) Member terhadap Non-member lebih besar dibandingkan dengan pengaruh Non-member terhadap Member dalam 2 Root dari 3 Root yang dihasilkan. Hasil ini menunjukan bahwa efek Mode, Gengsi, dan Pamer dari Member memang berpengaruh terhadap NonMember dan signifikan secara statistik.
\end{abstract}

Kata kunci: Analisis Interdependensi, Korelasi Kanonik, Permintaan Non-fungsional, Eigenvalue, Root 


\section{PENDAHULUAN}

\section{Latar Belakang}

Hukum Permintaan mentasbihkan bahwa hargalah - ceteris paribus - yang menentukan besar kecilnya permintaan. Artinya konsumen atau lebih tepatnya pembeli akan meningkatkan pembelian bila harga barang yang dimaksud untuk dibeli turun, demikian sebaliknya. Hukum ini ditasbihkan oleh Alfred Marshall berdasarkan pendekatan utilitas dengan menggunakan metode matematis yang bersifat deduktif. Padahal bisa saja permintaan tidak akan meningkat dalam kondisi yang ceteris paribus meskipun harga turun (berarti konsumen tidak rasional atau super rasional), konsep matematika yang digunakan selalu berpatokan pada kesimbangan Pareto dan syarat rasional, dengan demikian bila seseorang yang memiliki uang Rp.100 dan membeli barang X seharga Rp.10/unit, konsumen pasti mendapatkan 10 unit barang, bila harga turun menjadi Rp. 5/unit maka pasti mendapatkan 20 unit barang. Logika ini sebenarnya yang mengacaukan semua teori ekonomi dan turunannya, maka tak heran bila Ormerod mengatakan "ilmu ekonomi sudah mati”.

Ada bagian penting yang bukan sekedar kondisi faktor permintaan yang di-ceteris paribus-kan yang sangat berpengaruh terhadap permintaan seseorang. Hal ini telah lama dijelaskan oleh Veblen tetapi diabaikan oleh para ekonom mashab Cambridge, yaitu konsumsi budaya (efek Pamer). Maksudnya, seseorang akan membeli atau tidak membeli barang bukan karena harganya, tetapi jika barang tersebut merupakan barang yang memberikan efek pamer terhadap lingkungannya atau tidak.

Efek Pamer yang dimaksud, penulis tafsirkan bukan sekadar efek Pamer yang sering dilakukan oleh orang kaya dan sangat kaya. Akan tetapi, justru efek Pamer juga dilakukan oleh orang tak punya, miskin, dan bahkan melarat sekalipun. Ketika seseorang atau masyarakat meningkatkan pembelian atas suatu barang bukan lantaran harganya relatif murah (seperti fenomena permintaan HP dewasa ini), namun permintaan itu memang karena didasarkan pada tuntutan atau tren yang sedang terjadi. Meskipun dalam kondisi ceteris paribus, konsumen tidak akan menaikkan permintaan jika barang yang dimaksud bukan barang konsumsi yang menjadi tren dan tidak memberikan efek Pamer baginya. Sebaliknya, faktor Pamer yang justru meningkatkan permintaan meskipun harga barang naik - ceteris paribus.

Liebenstein menjelaskan bahwa efek ikut-ikutan dan gengsi sangat berpengaruh pada permintaan dalam kondisi hukum permintaan dan penawaran yang ceteris paribus. Akan tetapi, berbeda dengan efek Pamer (penulis jamin dengan kondisi relatif bahwa setiap orang yang membeli suatu produk pastilah tujuannya untuk Pamer baik dalam bentuk dipajang, diceritakan, digambar, difoto, atau semacamnya) tidak aneh bila melihat keluarga miskin sekalipun bersedia untuk menghabiskan tabungannya (bahkan berhutang) dalam rangka menyelenggarakan pesta sunatan anaknya demi bisa menyelenggarakan acara yang membuat kesan tidak memalukan kepada tetangganya, yang merupakan budaya masyarakat yang selalu menyertai dalam setiap konsumsinya maka efek ikut-ikutan masih terpengaruh oleh harga. Akan tetapi bukan karena harga konsumen melakukan permintaan, karena dorongan ikut-ikutan (band wagon effect) oleh konsumen lainnya untuk membeli. Metode ini banyak dilakukan oleh produsen dalam bentuk iklan yang mempergunakan para selebritis, praktik ghost shopping, dan fashion. Pusat perbelanjaan pun menggunakan konsep ini untuk menarik pengunjung sebanyak-banyaknya. Intinya efek ini yang justru memberikan dampak pada permintaan. Efek Pamer dan ikut-ikutan umumnya untuk kalangan derajat ekonomi apa saja bisa terjadi namun efek Gengsi adalah efek lain yang berpengaruh terhadap permintaan yang umumnya terjadi pada kalangan terbatas, misalnya orang kaya dan merasa kaya.

Efek Gengsi terhadap permintaan sehubungan dengan harga bertolak belakang dengan hukum permintaan. Permintaan yang disebabkan efek Gengsi justru akan meningkatkan permintaan pada saat harga barang tersebut naik (hal ini tidak berhubungan dengan barang Giffen), sebab naik atau 
tingginya harga barang dan mampu dibayar oleh konsumen menunjukan status ekonominya di kalangan masyarakat.

Hasil penelitian sebelumnya yang dilakukan terhadap responden yang termasuk dalam kelompok member Supermarket SKC di Pacific Palace, Jakarta, menghasilkan temuan bahwa efek Mode, Gengsi, dan Pamer berpengaruh secara signifikan terhadap keputusan pembelian baik secara bivariate maupun secara bersama. Dampak atau efek dari faktor non-fungsional terhadap permintaan itu menunjukkan bahwa 22\% disebabkan oleh efek Mode, 13\% oleh efek Gengsi, dan 46\% efek Pamer (Putong, 2010:12). Secara simultan (dengan asumsi faktor muatan variabel $\mathrm{Y}=1$ ), hasilnya menunjukkan bahwa 56\% faktor non-fungsional berpengaruh langsung terhadap permintaan; sedangkan sisanya ditentukan faktor lain (Putong4, 2010:18).

Hasil penelitian dengan data yang bersumber dari kelompok member bila diberlakukan secara umum untuk supermarket SKC di tempat lain dan supermarket lain sekelasnya menyimpulkan bahwa 56\% yang melakukan pembelian dikarenakan faktor non-fungsional. Sedangkan sisanya ditentukan oleh faktor non-fungsional lainnya (bila ada) dan faktor fungsional seperti harga, pendapatan, selera, dan lain-lain.

Menindaklanjuti hasil penelitian sebelumnya tentang pengaruh faktor permintaan nonfungsional terhadap permintaan, memang ada hal yang harus diteliti lebih lanjut, yaitu bahwa terlepas dari teori baku yang sudah ada, khusus untuk kasus dalam penelitian ini tidak bisa dipungkiri bahwa terdapat kelompok orang yang dapat terpengaruh oleh perilaku konsumsi kelompok member Supermarket SKC baik disadari ataupun tidak. Kelompok yang terpengaruh ini, dan kelak juga akan berpengaruh balik terhadap kelompok member, adalah kelompok pembeli non-member. Oleh karena pengaruh yang berdampak pada member dan sebaliknya tidak semata-mata antarvariabel faktor permintaan non-fungsional saja, melainkan berpengaruh secara serempak kepada semua variabel lainnya, analisis yang paling cocok digunakan adalah analisis Korelasi Kanonik (CanCor). Analisis ini dirasa cocok karena selain bersifat multivariat, juga bersifat multipel dan parsial, dan uniknya dilakukan secara bersama-sama (simultan).

\section{Permasalahan dan Batasan}

Masalah utama dalam penelitian ini adalah bagaimana pengaruh interdependensi variabel faktor permintaan non-fungsional kelompok member terhadap kelompok non-member dan sebaliknya. Penelitian ini mengabaikan dampak non-linier atas efek dari faktor permintaan non-fungsional. Faktor permintaan non-fungsional yang dimaksud dibatasi pada efek Mode, Gengsi, dan Pamer. Faktor nonfungsional lain seperti kebiasaan, adat istiadat, paksaan, atau keterbatasan dan lainnya tidak dibahas dan tidak termasuk dalam hasil analisis ini. Responden kelompok member adalah responden yang memiliki kartu anggota SKC dan aktif berbelanja minimal 2 kali dalam sebulan. Responden kelompok non-member adalah responden yang tidak memiliki kartu keanggotaan dan berbelanja minimal 1 kali dalam sebulan. Penelitian ini tidak membatasi responden berdasarkan tingkat dan ukuran kekayaan seperti jenis dan jumlah kendaraan, jumlah pendapatan, lokasi rumah dan tempat tinggal, asing atau non-asing, status sosial dan semacamnya.

\section{Tujuan dan Manfaat Penelitian}

Tujuan penelitian ini adalah untuk mengetahui dan menganalisis tentang bagaimana pengaruh interdependensi variabel faktor permintaan non-fungsional kelompok member terhadap kelompok non-member dan sebaliknya. Penelitian ini diharapkan memberikan manfaat kepada para penjual dan calon penjual terutama penjual yang setara dengan objek penelitian ini, meskipun dengan unit analisis yang berbeda, dalam menyikapi para konsumen (pelanggan dan calon pelanggan) sehingga ke depannya dapat dibentuk pola baru dalam menyiasati pemasaran yang efektif dan efisien. 


\section{Asumsi dan Hipotesis}

Asumsi dalam penelitian ini adalah responden bersikap irasional namun tetap realistis atas keputusan pembeliannya. Kondisi dummy diabaikan (usia, jenis kelamin, dan tingkat kekayaan). Asumsi klasik untuk persyaratan analisis data juga harus terpenuhi yaitu sebaran data normal, data homogen, tidak terdapat otokorelasi antara data dan yang utama adalah fungsinya bersifat linier (turunan pertama atas variabelnya adalah nilai variabel tersebut). Adapun hipotesis dalam penelitian ini adalah:

Tabel 1 Asumsi dan Hipotesis

\begin{tabular}{ll}
\hline Ho & $\begin{array}{l}\text { Efek Mode,Gengsi dan Pamer Kelompok Member tidak berpengaruh signifikan terhadap Efek } \\
\text { Mode dan Gengsi kelompok Non-Member secara simultan Kanonikal(semua root yang } \\
\text { terbentuk tidak signifikan) }\end{array}$ \\
\hline Ha & $\begin{array}{l}\text { Efek Mode,Gengsi dan Pamer Kelompok Member Berpengaruh positif signifikan terhadap } \\
\text { Efek Mode dan Gengsi kelompok Non-Member secara simultan Kanonikal (minimal terdapat } 1 \\
\text { root yang yang terbentuk signifikan) }\end{array}$ \\
\hline
\end{tabular}

Hipotesis ini akan diuji dengan tingkat kepercayaan sebesar 95\% dua arah dengan analisis Multivariat (MANOVA) atas kreteria Pillais, Hotellings, dan Wilks yang nilainya setara dengan Uji Design Analysis (Uji F). Khusus untuk uji korelasi interdependensi menggunakan uji Wilks dengan kreteria Chi-Square $\left(\chi^{2}\right)$ untuk alpha 5\% satu dan dua arah. Penelitian ini menggunakan software aplikasi pengolahan data statistik yaitu MSI Excel 2007 add-in dan SPSS versi 16. Untuk pengolahan data SPSS, digunakan program Syntax Editor yang disesuaikan dengan kebutuhan. Model Manual akan diberikan hanya untuk cetak biru.

\section{Landasan Teori}

Efek Gengsi, efek ikut-ikutan, dan efek Pamer dalam berkonsumsi adalah perilaku seseorang yang didasarkan pada sifat dan bawaan seseorang yang dipengaruhi oleh turunan, derajat kekayaan, dan lingkungan. Sebagaimana yang diteorikan oleh James Duesenberry yang menyatakan bahwa konsumsi seseorang itu selain dipengaruhi oleh pendapatannya juga dipengaruhi oleh lingkungannya (Putong, 2003:292). Dalam hal ini yang mendasari ketiga efek yang diteliti adalah perilaku, dimulai dari perilaku Konsumen.

Yang dimaksud dengan lingkungan bisa berasal dari lingkungan tempat tinggal, tempat kerja, tempat bergaul, dan tempat yang biasa dan sering dikunjungi. Teori ini adalah merupakan teori utama (grand theory) yang dijadikan pijakan analisis, sedangkan teori berikutnya adalah teori pendukung.

Perilaku konsumen adalah proses pengambilan keputusan yang mensyaratkan aktivitas individu untuk mengevaluasi, memperoleh, menggunakan, atau mengukur barang dan jasa (Laudon dan Bitta, 1998 dalam Simamora, 2002:2). American Marketing Association mendefinisikan perilaku konsumen sebagai "interaksi dinamis antara pengaruh dan kognisi, perilaku, kejadian di sekitar kita di mana manusia melakukan aspek pertukaran dalam hidup mereka.”

Perilaku konsumen adalah suatu proses untuk mengambil keputusan berdasarkan hasil evaluasi dan pengaruh baik dari dalam maupun dari luar. Mengambil keputusan untuk membeli atau tidak membeli adalah hasil dari pengaruh yang berasal dari dalam diri sendiri maupun dari luar. Dari dalam diri sendiri biasanya adalah efek dari pertanyaan "untuk apa ia harus membeli, bagaimana?". Sedangkan dari luar diri adalah "kapan ia harus membeli?". Efek Mode, Gengsi, dan Pamer adalah pertanyaan tentang untuk apa, bagaimana, dan kapan ia harus melakukannya. 
Menurut Kotler (2005:183-200), faktor-faktor yang memengaruhi keputusan pembelian konsumen antara lain budaya, kelas sosial, pribadi, keadaan ekonomi, dan psikologis. Keempat faktor ini akan membentuk dan memberikan efek Gengsi, ikutan-ikutan dan efek Pamer kepada konsumen dalam memutuskan apakah akan membeli suatu barang atau tidak .

Efek Gengsi atau sering juga disebut sebagai efek ikut arus atau efek Mode dengan menggunakan istilah bandwagon effect adalah efek yang memberikan dampak pada konsumen dalam melakukan permintaan bukan saja disebabkan oleh harga melainkan disebabkan juga oleh dorongan konsumen lain yang lebih dulu melakukan permintaan. Efek ikut-ikutan ini tidak berlaku untuk barang yang harganya terlalu tinggi dan juga terlalu rendah (Putong, 2009:48). Jadi kurva permintaanya mengikuti pola hukum permintaan tetapi terdapat batas atas dan batas bawah terhadap perubahan harga. Dalam konteks penelitian ini, persepsi konsumen menetapkan bahwa tempat mereka membeli adalah tempat yang menjual barang kebutuhannya dengan harga tidak terlalu tinggi namun juga tidak bisa dikatakan rendah atau murah untuk kalangan tertentu.

Dalam jurnal marketing oleh Roland Soong Vol IX (2002) dikatakan bahwa suatu pembeli mungkin dapat menekuni suatu bagian dari beberapa hal yang ada. Ketika korelasi positif, kita menghubungkannya dengan bandwagon effect, dan ketika korelasi negatif kita menghubungkannya dengan reverse bandwagon. Kita menyusun atau membentuk suatu jadwal permintaan dalam suatu tempat yg dipenuhi efek dan dengan asumsi sederhana dari penawaran (Amanta, 2009:19-21).

Efek Gengsi (snob effect) adalah efek yang memberikan dampak yang menurun pada permintaan bila harga suatu barang turun meskipun tetap dalam konteks hukum permintaan. Akan tetapi sedikit berbeda pada efek Gengsi dengan permintaan bersifat inelastis. Dalam artian, nilai akhir dari permintaan akan semakin tinggi bila harga barangnya tinggi (Putong, 2009:50). Dalam konteks penelitian ini persepsi konsumen menetapkan bahwa tempat mereka membeli adalah tempat yang menjual produk dengan harga yang relatif tinggi dan bergengsi.

Efek Pamer (veblen effect) adalah efek yang menyebabkan seorang konsumen melakukan pembelian (mengonsumsi) bila barang yang dibeli memberikan persepsi yang tinggi pada si pembeli, yang tujuannya adalah untuk pamer. Umumnya yang bisa dipamerkan dalam mengonsumsi suatu produk adalah harganya. Makin tinggi harga, makin tinggi nilai pamernya, sehingga hal itu menyebabkan konsumen akan meningkatkan pembelian meskipun harganya naik. Dalam hal ini kurva permintaan memiliki slope positif (Putong, 2009:50).

Dalam jurnal marketing oleh Laurie Simon Bagwell and B. Douglas Bernheim tahun 2003 (Veblen Effect in a Theory of Conspicious Consumption), Veblen effect lahir dari sebuah desakan atau hasrat untuk mendapatkan suatu penghargaan status sosial yang ditandai dengan kekayaan melalui conspicious consumption. Akan tetapi, Veblen effect tidak biasa lahir dari kepuasan single crossing property. Mereka mungkin muncul ketika suatu properti tersebut jatuh. Dalam kasus ini, budget merek adalah harga yang marjinal sehingga luxury brands tidak lagi superior atau terlihat mahal. Ketika suatu harga mahal akan membuat para pembeli mau untuk membeli karena melihat unsur luxury, dan kekayaan di dalamnya (Amanta, 2009: 19-21)

Secara teoretis, terbentuknya harga karena adanya kebutuhan dan kelangkaan suatu produk. Kebutuhan dan kelangkaan menciptakan permintaan. Permintaan dalam efek non-fungsional adalah bagian dari efek demonstrasi konsumen terhadap konsumen lainnya untuk menunjukan jati diri (baik kaya maupun miskin). Oleh karena itu, permintaan konsumen juga berpengaruh terhadap nilai ikutikutan, rasa gengsi, dan keinginan untuk pamer yang merupakan bagian dari budaya manusia sepanjang hayat hidupnya (Putong, 2005:190-191). 


\section{METODE PENELITIAN}

Analisis data dalam penelitian ini dilakukan pada 2011 berdasarkan data penelitian tahun 2009 dan diperbarui tahun 2010 (Desember) dari proyek penelitian untuk skripsi yang dilakukan oleh Amanta. Objek Penelitian ini adalah responden Supermarket X, berlokasi di Pacific Palace, Jakarta Pusat.

Jenis data yang digunakan untuk analisis dalam penelitian ini adalah data kualitatif yang dikuantitatifkan dan bersifat sekunder yang bersumber dari skripsi Amanta (2009). Sementara sumber data yang digunakan Amanta (2009) adalah data primer dengan menggunakan instrumen kuesioner yang bersifat tertutup dengan menggunakan skala ukur Semantic diferensial (perbedaan atas penilaian didasarkan pada penentuan nilai terendah dan tertinggi) dengan skala pengukuran interval yang memiliki rentang 1 dengan nilai terendah 1 (sangat tidak setuju) dan tertinggi 7 (sangat setuju). Semua data yang berasal dari 50 responden dengan 22 butir pernyataan yang bersifat perseptif secara secara eksternal terdapat 5 responden member yang tidak valid karena tidak mengisi lengkap dan adanya jawaban yang diganti, sehingga dirasakan perlu untuk menyetarakannya dengan responden nonmember. Dengan demikian, data yang lolos untuk ditabulasi adalah berasal dari 45 responden. Data yang telah ditabulasi kemudian dilakukan uji kalibrasi (uji validitas dan reliabilitas untuk nilai " $r$ " kritis sebesar 0,294), telah dilakukan uji asumsi klasik untuk normalitas data (berdasarkan nilai Zscore), pembuktian data bersifat homogen, non-autokorelasi, dan linier (uji regresi dan Rank Spearman Correlation). Hasilnya menunjukan data layak dianalisis secara statistik inferensial

Sebagaimana penjelasan di atas, berikut ditabulasi variabel yang akan dianalisis yaitu 3 variabel independen-dependen dan 3 variabel dependen-independen sebagai berikut.

Tabel 2 Variabel yang Dianalisis

\begin{tabular}{lccc}
\hline \multicolumn{2}{c}{ Variabel Independen dependen } & \multicolumn{2}{c}{ Variabel Dependen independen } \\
\hline M1 & Wagon effect/Mode & NM1 & Wagon effect/Mode \\
M2 & Snob effect /Gengsi & NM2 & Snob effect /Gengsi \\
M3 & Veblen effect/Pamer & NM3 & Veblen effect/Pamer \\
\hline
\end{tabular}

Keterangan:

$M=$ Kelompok Member

$N M=$ Kelompok Non-Member

Variabel ini akan dianalisis dengan Korelasi Kanonik (CanCor) dengan model sebagai berikut.

Model Dasar:

$$
B(X 1+X 2+X 3)=B(Y 1+Y 2+Y 3) \ldots \ldots \ldots \ldots \ldots \ldots \ldots \ldots \ldots \ldots \ldots \ldots \ldots \ldots \ldots \ldots \ldots
$$

Berdasarkan model dasar ini akan terbentuk matriks korelasi sebanyak 12 orde yang terbagai dalam 4 kelompok matriks yang terdiri dari 3 orde tiap kelompok. Matriks tersebut adalah sebagai berikut. 


$$
\begin{aligned}
& R_{x x}=\left[\begin{array}{lll}
r_{M 11} & r_{M 12} & r_{M 13} \\
r_{M 21} & r_{M 22} & r_{M 23} \\
r_{M 31} & r_{M 32} & r_{M 33}
\end{array}\right] R_{x y}=\left[\begin{array}{lll}
r_{M 1 N M 1} & r_{M 1 N M 2} & r_{M 1 N M 3} \\
r_{M 2 N M 1} & r_{M 2 N M 2} & r_{M 2 N M 3} \\
r_{M 3 N M 1} & r_{M 3 N M 2} & r_{M 3 N M 3}
\end{array}\right] \\
& R_{y y}=\left[\begin{array}{lll}
r_{N M 11} & r_{N M 12} & r_{N M 13} \\
r_{N M 21} & r_{N M 22} & r_{N M 23} \\
r_{N M 31} & r_{N M 32} & r_{N M 33}
\end{array}\right] R_{y x}=\left[\begin{array}{lll}
r_{N M 1 M 1} & r_{N M 1 M 2} & r_{N M 1 M 3} \\
r_{N M 2 M 1} & r_{N M 2 M 2} & r_{N M 2 M 3} \\
r_{N M 3 M 1} & r_{N M 3 M 2} & r_{N M 3 M 3}
\end{array}\right] \\
& r_{M 11}=r_{M 22}=r_{M 33}=r_{N M 11}=r_{N M 22}=r_{N M 33}=1
\end{aligned}
$$

Berdasarkan 4 macam matriks ini maka akan didapat model matriks $R$ untuk menentukan nilai Eigenvalue dan Eigenvector sebagai berikut.

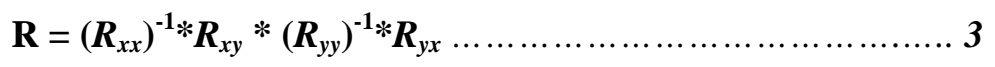

Hasil perkalian antarmatriks ini pada akhirnya menghasilkan 1 matriks yang berorde $3 \mathrm{X} 3$ sebagai berikut.

$$
R=\left[\begin{array}{lll}
R_{a} & R_{b} & R_{c} \\
R_{d} & R_{e} & R_{f} \\
R_{g} & R_{h} & R_{i}
\end{array}\right]
$$

Berdasarkan matriks ini dapat diketahui bahwa akan terdapat tiga Eigenvalue untuk tiga rootvariat (covariat $=\mathrm{CV}$ ). Tiga CV ini digunakan semuanya atau tidak bergantung pada signifikansi uji MANOVA. Eigenvalue setara dengan nilai determinasi antarvariabel yaitu $\mathrm{R}^{2}$. Modelnya adalah sebagai berikut.

$R-\lambda I$

$\left[\begin{array}{lll}R_{a} & R_{b} & R_{c} \\ R_{d} & R_{e} & R_{f} \\ R_{g} & R_{h} & R_{i}\end{array}\right]-\left[\begin{array}{ccc}\lambda & 0 & 0 \\ 0 & \lambda & 0 \\ 0 & 0 & \lambda\end{array}\right]=\left[\begin{array}{ccc}\left(R_{a}-\lambda\right) & R_{b} & R_{c} \\ R_{d} & \left(R_{e}-\lambda\right) & R_{f} \\ R_{g} & R_{h} & \left(R_{i}-\lambda\right)\end{array}\right]$ .5

Tentu saja nilai Eigenvalue akan mudah ditentukan nilainya bila saja $R b, R c, R d, R f, R g$, $d a n$ $R h$ sama dengan nol, nilainya akan setara dengan:

$$
\begin{aligned}
& \left(R_{a}-\lambda\right)\left(R_{e}-\lambda\right)\left(R_{i}-\lambda\right) \\
& \lambda_{1}=R_{a}=R_{1}{ }^{2} \\
& \lambda_{2}=R_{e}=R_{2}{ }^{2} \\
& \lambda_{3}=R_{i}=R_{3}{ }^{2}
\end{aligned}
$$


Untuk matriks yang berorde $2 \times 2$, maka penyelesaian dengan menggunakan rumus $A B C$ atau kuadrat-sempurna akan dengan mudah dilakukan, tetapi untuk yang berorde $3 \times 3$ dan di atasnya sangat membuang waktu dan tenaga. Oleh karena itu, sebaiknya digunakan SPSS (seluruh hasil) atau Maple (untuk matriksnya saja) atau E-Views, StatistiXL, dan SAS (seluruh hasil). Yang terpenting adalah nilai determinasi kanonik ditentukan dengan menggunakan model tersebut di atas.

Setelah diketahui nilai Eigenvalue, maka berikutnya adalah menentukan nilai $\chi^{2}$ untuk uji hipotesis model Covariate. Uji ini setara dengan uji F pada ANOVA yang bertujuan untuk mengetahui jika model secara umum signifikan atau tidak. Rumusnya adalah:

$$
\begin{aligned}
& \chi^{2}=-\left[N-1-\left(\frac{k x+k y+1}{2}\right)\right] \operatorname{Ln} \Lambda_{m} \\
& \operatorname{Ln} \Lambda_{m}=\prod\left(1-\lambda_{i}\right) \\
& D f=\left(k_{x}\right)\left(k_{y}\right)
\end{aligned}
$$

$N=$ Jumlah amatan (dalam kontek penelitian ini sebanyak 45)

$k x=$ jumlah faktor variabel $X$ (dalam konteks penelitian ini sebanyak 3$)$

$k y=$ jumlah faktor variabel $Y$ (dalam konteks penelitian ini sebanyak 3$)$

$\Lambda_{m}=$ Irisan nilai 1 - Eigenvalue sejumlah $m$ (dalam konteks penelitian ini $m=3$ )

Dengan demikian bila:

$\Lambda_{3}$, artinya: $\left(1-\lambda_{1}\right)\left(1-\lambda_{2}\right)\left(1-\lambda_{3}\right)$ setara dengan $\left(1-R_{1}{ }^{2}\right)\left(1-R_{2}{ }^{2}\right)\left(1-R_{3}{ }^{2}\right)$

$D f=$ Derajat Bebas (Degree of Freedom) untuk derajat Alpha $=$ ?

Bila signifikan, analisis akan dilanjutkan untuk menentukan nilai koefisien korelasi kanonik. Dalam konteks kanonik, istilahnya adalah Loading Factors (LF). Rumusnya adalah:

$$
\begin{aligned}
& L F_{X}=R_{x x} * B_{x}, L F_{Y}=R_{y y} * B_{y} \\
& B_{x}=R_{x x}^{-1} * R_{x y} * \hat{B}_{y} \\
& \hat{B}_{y}=\left[\prod B_{y}\right] * \frac{1}{\lambda_{i}} \\
& B y=\left[R_{y y}{ }^{-1 / 2}\right]^{T} *\left[B_{y}^{e v}\right]
\end{aligned}
$$

$B_{X}=$ Koefisien Kanonik Variabel dalam roots variat $X$

$B_{y}=$ Koefisien Kanonik Variabel dalam roots variants $Y$

$B_{y}{ }^{e v}=$ Normaliasi Koefisien matrik eigenvector roots variat $Y$

$\hat{B}_{y}=$ Matriks Korelasi Variabel dalam roots variat $Y$

$\lambda=$ EigenValue $=R^{2}$ untuk masing-masing roots variat

$\left[R_{y y}{ }^{-1 / 2}\right]^{T}=$ Transpose dari invers matrik dalam roots variat $Y$ 
Berdasarkan nilai LF inilah kemudian dapat ditentukan nilai rata-rata LF masing-masing CV. Dalam konteks kanonik, disebut Share of Varians (SV). Lalu dilanjutkan dengan penentuan nilai korelasi interdependensi yang disebut sebagai Redundancy Index (RI), modelnya adalah:

$$
\begin{aligned}
& S V_{X}=\frac{\sum\left(L F_{x}\right)^{2}}{k_{x}} \\
& R I_{X}=S V_{X}^{* \lambda_{x}} \\
& S V_{Y}=\frac{\sum\left(F_{y}\right)^{2}}{k_{y}} \\
& R I_{Y}=S V_{Y} * \lambda_{y}
\end{aligned}
$$
9

Sampai ditemukan nilai RI, maka sebenarnya analisis korelasi kanonik sudah cukup. Akan tetapi, bila peneliti ingin melanjutkan analisisnya lebih mendalam, dapat ditentukan nilai koefisien regresinya sebagaimana model regresi konvensional multipel dengan pendekatan multivariate sebagai berikut.

$$
\begin{aligned}
& B_{i x}=\beta_{x . x i}\left[\frac{\sigma_{Y}}{\sigma_{i x}}\right] \rightarrow \beta_{x 1 . x 2}=\frac{\left[r_{x_{1} y}\right]-\left[r_{x_{2} y}\right]}{1-\left[r_{x 1 x 2}\right]^{2}} \\
& B_{i y}=\beta_{y . y i}\left[\frac{\sigma_{X}}{\sigma_{i y}}\right]
\end{aligned}
$$

Untuk selanjutnya, analisis data didasarkan pada pengolahan data menggunakan SPSS versi 16 dengan menggunakan metode syntax (bahasa pemrograman khusus untuk data MACRO SPSS). Syntax dalam konteks data yang digunakan dalam penelitian ini adalah sebagai berikut.

\section{Syntax 1}

MANOVA $x 1$ to $x 3$ WITH $y 1$ to $y 3$

/PRINT=ERROR (SSCP COV COR) SIGN

(HYPOTH EIGEN DIMENR)

/DISCRIM=RAW STAN ESTIM COR ALPHA(0.05).

Atau, bila diinginkan dilakukan proses rotasi varimax, syntax-nya adalah:

\section{Syntax 2}

TITLE 'CANONICAL CORR WITH MANOVA AND VARIMAX ROTATION' .

MANOVA $x 1$ to $x 3$ with $y 1$ to $y 3$

/DISCRIM ALL ALPHA (0.05) ROTATE(VARIMAX)

/PRINT SIGNIF(EIGN DIMENR HYPOTH). 


\section{HASIL DAN PEMBAHASAN}

Data sebagaimana yang dilampirkan telah melalui tahapan uji kalibrasi dan uji asumsi klasik dan memenuhi semua syarat yang diperlukan untuk dianalisis dengan model Korelasi Kanonik dengan didukung dasar teori yang cukup mapan. Analisis awal adalah menentukan matriks korelasi faktor variabel $\mathrm{X}$ dan $\mathrm{Y}$, dan hasilnya adalah sebagai berikut.

Tabel 3 Matriks Korelasi, Mean, dan Standar Deviasi Member dan Non-member

\begin{tabular}{|c|c|c|c|c|c|c|}
\hline \multirow{2}{*}{ Variabel } & \multicolumn{3}{|c|}{$\boldsymbol{R}_{X X}$} & \multicolumn{3}{|c|}{$\boldsymbol{R}_{x y}$} \\
\hline & M1 & M2 & M3 & NM1 & NM2 & NM3 \\
\hline M1 & 1 & .298 & -.629 & .103 & -.559 & .712 \\
\hline M2 & .298 & 1 & -.080 & -.371 & .141 & .415 \\
\hline \multirow[t]{2}{*}{ M3 } & -.629 & -.080 & 1 & -.275 & .751 & -.867 \\
\hline & \multicolumn{3}{|c|}{$\boldsymbol{R}_{y x}$} & \multicolumn{3}{|c|}{$\boldsymbol{R}_{y y}$} \\
\hline NM1 & .103 & -.371 & -.275 & 1 & -.509 & .192 \\
\hline NM2 & -.559 & .141 & .751 & -.509 & 1 & -.652 \\
\hline NM3 & .712 & .415 & -.867 & .192 & -.652 & 1 \\
\hline STDEV & .08474 & .06539 & .10812 & .08479 & .17411 & .52617 \\
\hline Mean & 5.1484 & 5.3020 & 5.1209 & 4.1669 & 4.2842 & 5.0500 \\
\hline
\end{tabular}

Sumber: Output SPSS

Keterangan: Nilai TDEV dan Mean digunakan untuk perhitungan coefficient CanCor

Nilai korelasi pada tabel 3 ini menunjukan hubungan bivariate (single - sederhana) antara variabel permintaan non-fungsional dari Member (M) terhadap Non-member (NM).

Dapat dijelaskan untuk kasus hubungan antara M1 terhadap NM3, maksudnya pengaruh Efek Mode M terhadap efek Pamer NM sebesar 0,712 (relatif kuat), hubungan antara Efek Mode M terhadap Efek Mode NM sebesar 0,103 (sangat rendah). Dalam konteks ini dapat dijelaskan bahwa Efek Mode M justru kuat pengaruhnya terhadap efek Pamer NM ketimbang pada efek yang sama terhadap NM. Sebaliknya nilai hubungannya sama besarnya. Untuk mengetahui jika ada perbedaan atau tidak antara efek Mode M terhadap NM dan sebaliknya, maka perlu ditentukan nilai korelasi kanoniknya.

Matriks Rxx dan Ryy di atas diubah terlebih dahulu dalam bentuk matriks invers agar hasil kali matriks asal dengan inversnya menghasilkan matriks identitas, I, hasil normalisasi matriks $R x x$ dan Ryy adalah sebagai berikut.

$$
R_{x x}{ }^{-1}=\left[\begin{array}{ccc}
1.84 & -0.46 & 1.12 \\
-0.46 & 1.12 & -0.20 \\
1.12 & -0.20 & 1.69
\end{array}\right] R_{y y}{ }^{-1}=\left[\begin{array}{ccc}
1.42 & 0.94 & 0.34 \\
0.94 & 2.37 & 1.36 \\
0.34 & 1.36 & 1.82
\end{array}\right]
$$

Selanjutnya dengan menggunakan model pada bagian III di atas atau langsung dengan menggunakan SPSS hasilnya dapat diketahui dengan lebih cepat dan akurat sebagai berikut: 
Tabel 4 Nilai CanCor, Eigenvalue, dan Signifikansi

\begin{tabular}{cccl}
\hline Root & CanCor & Sq.Cor $(\boldsymbol{\lambda})$ & \multicolumn{1}{c}{ Sig.F } \\
\hline 1 & 0.94650 & 0.89 & Pillais $=0.00$ \\
2 & 0.65429 & 0.42 & Hotellings $=0.00$ \\
3 & 0.09778 & 0.008 & Wilks $=0.00$ \\
\hline
\end{tabular}

Sumber: Output SPSS

Analisis kanonikal ini akan menghasilkan 3 Variate yang masing-masing variat disebut Root (akar) dari model yang terbentuk. Tiga variat yang terbentuk akan menjelaskan hubungan timbal balik antara variabel permintaan M terhadap NM dan sebaliknya.

Berdasarkan tabel 4 dapat diketahui nilai korelasi kanonik untuk root 1 antara M dan NM dan sebaliknya sebesar 0.95. Artinya, hubungannya sangat kuat, masing-masing variabel berpengaruh sebesar 89\% dan signifikan secara statistik dengan alpha 5\%. Root 2 menunjukan hubungan antara M terhadap NM dan sebaliknya sebesar 0.65 (hubungan relatif sedang) dengan pengaruh sebesar $42 \%$ dan signifikan secara statistik). Root nomor 3 memiliki korelasi yang sangat rendah dan cenderung tidak memiliki hubungan karena pengaruhnya hanya sebesar $0.8 \%$, dan signifikan secara statistik.

Untuk mengetahui apakah Root 3 dapat digunakan untuk menjelaskan hubungan dan pengaruh antarvariabel M dan NM atau sebaliknya, maka perlu dilakukan analisis signifikansi antara root 1, 2, dan 3 terhadap root 3 . Hasilnya dengan menggunakan model uji Wilks berdasarkan output SPSS adalah sebagai berikut: Root 1 ke 3 signifikansi F sebesar 0.00; Root 2 ke 3 signifikansi sebesar 0.00; dan Root 3 ke 3 sebesar 0.533. Berdasarkan uji signifikansi ini, maka dapat diketahui bahwa root nomor 3 tidak bisa digunakan untuk menjelaskan pengaruh variabel M dan NM serta sebaliknya. Oleh karena hanya root 1 dan 2 yang akan digunakan, maka hanya root 1 dan 2 saja yang dihitung nilai korelasinya. Nilai korelasi dalam variabel M dan NM masing-masing akan membentuk 2 fungsi variat, yang nilainya adalah sebagai berikut.

Tabel 5 Nilai CanCor dan Sq.Cor Variabel M Root 1

\begin{tabular}{|c|c|c|c|c|}
\hline \multirow{2}{*}{ Variabel } & \multicolumn{4}{|c|}{ Fungsi } \\
\cline { 2 - 5 } & $\mathbf{1}$ & $\mathbf{2}$ & $\mathbf{1}$ & $\mathbf{2}$ \\
\cline { 2 - 5 } & Korelasi Kanonik - LF1 & $\mathbf{0 . 5 9 2 9}$ & 0.0144 \\
\hline M1 & $\mathbf{- 0 . 7 7 ( - 0 . 1 8 )}$ & 0.12 & 0.1849 & $\mathbf{0 . 7 9 2 1}$ \\
\hline M3 & -0.43 & $\mathbf{- 0 . 8 9 ( - 0 . 9 9 )}$ & $\mathbf{0 . 8 4 6 4}$ & 0.1089 \\
\hline \multicolumn{4}{|c}{ Sumber: Output SPSS } \\
\hline
\end{tabular}

Keterangan: angka dalam kurung adalah nilai standardized coefficient corr.

Berdasarkan tabel 5 di atas dapat dijelaskan bahwa pengaruh antara variabel $\mathbf{M}$ terhadap permintaan non-fungsional dengan kontribusi terbesar diberikan oleh M1 (59.3\%) dan M3 (85\%) pada fungsi kanonik 1, dan M2 (79\%) pada fungsi kanonik 2.

Pada Root 1 fungsi kanonik 1 hubungan antara M1 terhadap Permintaan Non-fungsional nya bersifat trade off. Artinya untuk setiap peningkatan efek Mode rata-rata sebesar satu skala persepsi justru akan menurunkan permintaan non-fungsional sebesar 0.18 satuan skala persepsi. Sedangkan M3 (efek pamer) memberikan dampak positif 0.78, M2 (gengsi) pada fungsi kanonikal 2 memberikan dampak negatif sebesar 0.99 . 
Dalam pengertian yang sederhana bisa dijelaskan bahwa kelompok member dalam berbelanja di SKC bukan karena ikut-ikutan atau karena efek Mode, sehingga mereka akan menurunkan berbelanjanya jika dirasa hal itu merupakan dampak Mode. Demikian juga dengan M2 (Gengsi) yang dijelaskan oleh fungsi kanonik 2, menunjukan bahwa member akan menurunkan berbelanjanya jika persepsi mereka berbelanja di SKC karena efek Gengsi. Dan ternyata hal yang mendorong member untuk selalu meningkatkan berbelanjanya di SKC adalah efek Pamer yang oleh Veblen dikatakan sebagai konsumsi budaya, bahwa setiap orang pada dasarnya ingin memamerkan barang dan cara mereka mengonsumsi. Yang terpenting untuk harus diingat adalah bahwa pola konsumsi yang dilakukan oleh para member ini sudah memperhitungkan efek lainnya dari efek yang langsung berpengaruh. Maksudnya adalah jika efek Mode yang berpengaruh, Gengsi dan Pamer juga dilibatkan secara bersama-sama namun efeknya dianggap tetap atau sudah diwakilkan pada efek yang langsung berpengaruh. Perhatikan kembali nilai Determinasi kanonik fungsi 1 untuk M2 dan fungsi 2 untuk M1 dan M3, meskipun kecil tetap saja ada.

Untuk Root 2 nilai korelasinya adalah sebagai berikut.

Tabel 6 Nilai CanCor dan Sq.Cor Variabel NM Root 2

\begin{tabular}{|c|c|c|c|c|}
\hline \multirow{3}{*}{ Variabel } & \multicolumn{4}{|c|}{ Fungsi } \\
\hline & \multicolumn{2}{|c|}{ Korelasi Kanonik - LF2 } & \multicolumn{2}{|c|}{ Determinasi Kanonik } \\
\hline & 1 & 2 & 1 & 2 \\
\hline NM1 & -0.12 & $0.71(0.31)$ & 0.0144 & 0.5041 \\
\hline NM2 & $0.68(0.14)$ & $-0.72(-1.1)$ & 0.4624 & 0.5184 \\
\hline NM3 & $-0.99(-0.92)$ & -0.02 & 0.9801 & 0.0004 \\
\hline
\end{tabular}

Sumber: Output SPSS

Keterangan: angka dalam kurung adalah nilai standardized coefficient corr.

Berdasarkan tabel 6 di atas dapat dijelaskan bahwa pengaruh antara variabel NM terhadap permintaan non-fungsionalnya pada fungsi kanonik 1 kontribusi terbesar diberikan oleh NM3 (98\%) dan NM2 (46.2\%). Sedangkan pada fungsi kanonik 2 kontribusi terbesar disumbangkan oleh NM1 (50.4\%) dan NM2 (51.8\%).

Root 2 fungsi kanonik 1, pengaruh antara NM2 (Gengsi) terhadap permintaan Non-fungsional bersifat positif sebesar 0.14 untuk setiap kenaikan rata-rata satu skala persepsi atas efek Gengsi. Efek Pamer memberikan dampak negatif pada permintaan sebesar 0.92 untuk setiap kenaikan rata-rata satu skala persepsinya. Fungsi 1 root 2 ini menjelaskan bahwa semakin tinggi nilai persepsi dari efek Pamer, maka permintaannya akan turun. Artinya, konsumen non-member ini dalam berbelanja di SKC tidak didasarkan atas keinginan untuk Pamer, melainkan untuk meningkatkan Gengsi (NM2).

Pada fungsi 2, pengaruh NM1 terhadap permintaan bersifat positif sebesar 0.31 untuk setiap kenaikan rata-rata satu skala persepsi efek Mode. Sedangkan efek Gengsi memberikan dampak negatif pada permintaan sebesar 1.1 untuk setiap kenaikan rata-rata satu skala persepsi. Hal ini menjelaskan bahwa non-member akan meningkatkan berbelanjanya apabila efek Gengsi diturunkan. Sedangkan bila efek Mode dinaikan, maka akan meningkatkan berbelanjanya. Dalam pengertian yang sederhana, non-member dapat ditarik untuk berbelanja bila ada dorongan yang kuat dari pembeli sebelumnya (efek Mode ditingkatkan) dan efek Gengsinya diturunkan.

Berdasarkan tabel 4, secara keseluruhan hubungan antara permintaan Non-fungsional member terhadap permintaan Non-fungsional non-member dalam root 1 sebesar 0.95 (sangat kuat) dengan kontribusi sebesar 89\%. Root 2 hubungannya sebesar 0.65 (lumayan kuat) dengan kontribusi sebesar $42 \%$. Hubungan dan determinasi ini bersifat causal (sebab-akibat) antara M terhadap NM dan NM terhadap M. 
Analisis kanonikal yang bersifat interdependensi dapat dilakukan karena uji Multivariate (MANOVA) terhadap seluruh variabel yang digunakan signifikan secara statistik (tabel 4). Untuk melakukan analisis kanonikal interdependensi, maka perlu dihitung terlebih dulu nilai Share of Varians (SV) sehingga akan dapat dihitung nilai Redundancy Index (RI) sebagai berikut.

$$
\begin{aligned}
& S V_{X 1-1}=\frac{\sum\left(L F_{x 1-1}\right)^{2}}{k_{x}}=\frac{0.5929+0.1849+0.8464}{3}=0.541 \\
& S V_{X 1-2}=\frac{\sum\left(L F_{x 1-2}\right)^{2}}{k_{x}}=\frac{0.0144+0.7921+0.1089}{3}=0.305 \\
& R I_{X 1-1}=S V_{X 1-1} * \lambda_{x 1}=(0.541)(0.89)=0.48 \\
& R I_{X 1-2}=S V_{X 1-2} * \lambda_{x 2}=(0.305)(0.42)=0.13 \\
& S V_{Y 1-1}=\frac{\sum\left(L F_{y 1-1}\right)^{2}}{k_{y}}=\frac{0.0144+0.4624+0.9801}{3}=0.486 \\
& S V_{Y 1-2}=\frac{\sum\left(L F_{y 1-2}\right)^{2}}{k_{y}}=\frac{0.5041+0.5184+0.0004}{3}=0.341 \\
& R I_{Y 1-1}=S V_{Y 1-1} * \lambda_{y 1}=(0.486)(0.89)=0.43 \\
& R I_{Y 1-2}=S V_{Y 1-2} * \lambda_{y 2}=(0.341)(0.42)=0.14
\end{aligned}
$$

Korelasi Interdependensi ini diuji, apakah signifikan atau tidak dengan menggunakan model 7, hasilnya adalah sebagai berikut.

$$
\begin{aligned}
& \operatorname{Ln} \Lambda_{2}=\prod\left(1-\lambda_{i}\right)=\operatorname{Ln}(1-0.89)(1-0.65)=\operatorname{Ln}(0.11)(0.35)=\operatorname{Ln}(0.0385)=-3.257 \\
& \chi^{2}=-\left[N-1-\left(\frac{k x+k y+1}{2}\right)\right] \operatorname{Ln} \Lambda_{m} \Leftrightarrow-\left[45-1-\left(\frac{3+3+1}{2}\right)\right]-3.257 \\
& \chi_{\text {hitung }}^{2}=-[44-(3.5)] *-3.257=(-40.5)(-3.257)=131.91 \\
& D f=\left(k_{x}\right)\left(k_{y}\right)=(3)(3)=9, \alpha=5 \% \\
& \chi_{\text {tabel }}^{2}(5 \%, 2.5 \%)=16.92,19.02<131.91
\end{aligned}
$$

Secara keseluruhan, hasil perhitungan yang terdapat pada tabel 3, 4, 5, 6 serta hasil perhitungan yang menggunakan model 9 di atas dapat dirangkum dalam 2 root dan 2 covariates sebagai berikut. 

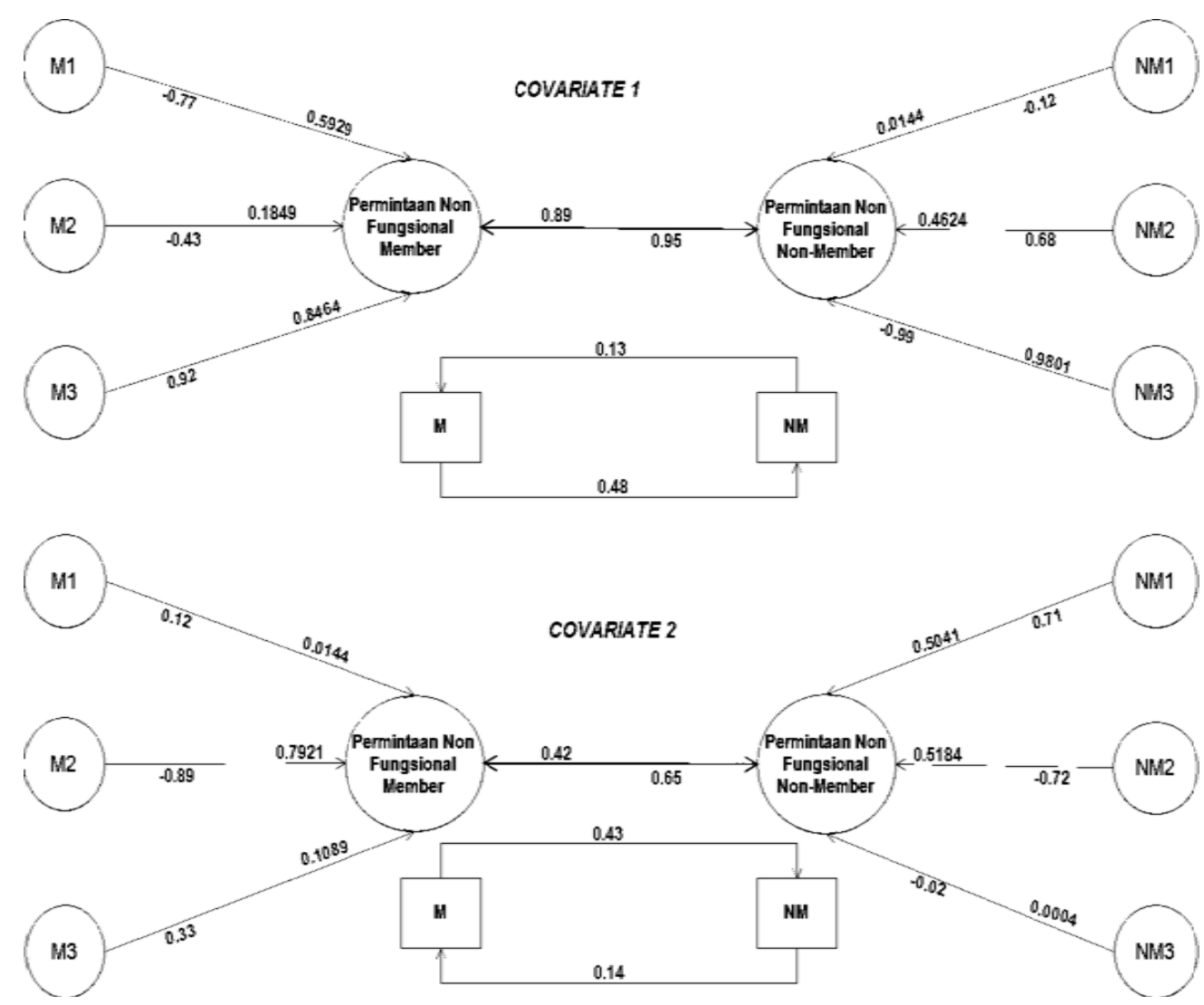

Gambar 1 Roots dan Covariates

Keterangan: Angka di atas garis dalam Root 1 dan 2 adalah nilai (LF) ${ }^{2}$, setara dengan $\mathrm{R}^{2}$

Hasil perhitungan Redundancy Index pada Covariate 1 menunjukkan bahwa besarnya pengaruh efek permintaan Non-fungsional member terhadap non-member sebesar $48 \%$, sedangkan pengaruh non-member terhadap member sebesar 13\%. Hal ini mengindikasikan bahwa kelompok member lebih dominan berpengaruh terhadap kelompok non-member. Sedangkan sebaliknya, meskipun kecil tetap berdampak juga, dalam pengertian yang lebih dalam informasi angka ini memberikan gambaran bahwa ternyata dampak member kepada non-member justru menyebabkan member terpengaruh untuk lebih meningkatkan berbelanjanya atas efek yang mereka tebarkan. Hampir tidak berbeda dengan hasil perhitungan pada covariate 1, perhitungan pada covariate 2 juga menunjukkan hal yang relatif sama, dengan member berpengaruh sebesar $43 \%$ terhadap non-member. Sebaliknya non-member hanya berpengaruh sebesar 14\% terhadap member.

Nyata kedua Root di atas menjelaskan melalui 2 fungsi (covariate) yang dihasilkan bahwa kelompok non-member memang terpengaruh oleh kelompok member sehubungan dengan perilakunya sebagai konsumen dalam membelanjakan uangnya.

\section{SIMPULAN}

Berdasarkan hasil analisis, dapat disimpulkan bahwa bahwa penelitian ini secara statistik menolak Hipotesis $\mathrm{Nol}\left(\mathrm{H}_{0}\right)$. Dan dengan demikian maka dapat dibuktikan bahwa ternyata terdapat pengaruh yang nyata dalam 2 dari 3 root yang membentuk masing-masing 2 fungsi antara Permintaan Non-fungsional Kelompok Member terhadap Kelompok Non-member. Demikian juga sebaliknya. 
Pengaruh interdependensi antara Member dan Non-Member menunjukan bahwa kelompok Member lebih dominan terhadap kelompok Non-Member dibandingkan sebaliknya.

Analisis data dalam penelitian ini menunjukan bahwa ternyata bagi konsumen yang telah merasa bahwa posisi sosial dan ekonominya di atas rata-rata masyarakat umumnya (yang dikonotasikan sebagai member dalam penelitian ini) membelanjakan uangnya tidak dikarenakan ikut Mode, melainkan karena ingin Pamer di satu sisi dan di sisi lain untuk meningkatkan Gengsi. Sebaliknya bagi yang terpengaruh oleh perilaku konsumen yang mengutamakan gengsi dan pamer, akhirnya ikut-ikutan untuk berusaha masuk dalam kelas kelompok masyarakat yang berstatus sosial dan ekonomi yang mapan.

Informasi ini jelas sangat penting bagi produsen khususnya SKC atau yang setara dengan SKC di daerah lainnya yang memosisikan jualan produknya untuk dan hanya pada kelas masyarakat yang berstatus sosial dan ekonomi yang mapan. Dengan demikian produsen harus berusaha menjaga dengan cara apa pun untuk tetap memberikan fasilitas dan ruang kepada konsumennya yang member agar tetap terjaga rasa gengsi dan pamernya kepada produsen dan orang lain (non-member), sehingga akan tetap membelanjakan uangnya pada produsen tersebut, yang juga memberikan tambahan keuntungan langsung kepada produsen karena dampaknya jumlah pembeli semakin meningkat dengan berdatangan para pembeli yang terpengaruh karena ingin ikut-ikutan pamer dan meningkatkan gengsi.

Implikasi dari hasil penelitian ini bila dimanfaatkan adalah sebagaimana seharusnya tentu saja akan berdampak pada keuntungan yang semakin besar karena jumlah pelanggan semakin bertambah. Bila hasil penelitian ini diabaikan, minimal sebagai masukan, maka dampaknya adalah produsen akan tetap puas dengan hasil yang telah mereka capai sebelumnya. Berarti mereka tidak perlu melakukan hal-hal sebagaimana seharusnya (sesuai hasil penelitian ini), dan pada suatu saat produsen seperti SKC akan semakin banyak (persaingan ketat), maka SKC atau semacamnya akan mengalami kerugian, minimal kerugian keuntungan yang seharusnya mereka dapatkan tidak bisa mereka dapatkan (opportunity loss).

Analisis data dalam penelitian ini banyak meninggalkan informasi lain yang juga penting seperti analisis Croos Loading, Raw CanCoef, Analisis Regresi (khusus analisis Regresi Kanonikal akan dimuat dalam artikel tersendiri) dan analisis lebih mendalam yang menunjukan ternyata adanya nilai CanCorr baru yang tercipta pada kelompok Member dengan mengabaikan root 2 dan 3. Kepada peneliti lainnya sangat disarankan untuk meneliti lebih lanjut model penelitian ini sesuai dengan konteks yang ada di daerah masing-masing, dengan menambahkan fokus selain yang sudah dijelaskan pada penelitian ini

\section{DAFTAR PUSTAKA}

Aczel, A. D., and Sounderpandian, J. (1999). Complete Business Statistics. McGraw-Hill/Irwin.

Amanta, A. A. (2009). Analisis Pengaruh Permintaan Non-fungsional terhadap Keputus Pembelian Konsumen. Skripsi. Jakarta: BINUS University.

Dumairy. (2000). Matematika Terapan Untuk Bisnis dan Ekonomi. Yogyakarta: BPFE.

Putong. (2003). Pengantar Ekonomi Mikro dan Makro. Jakarta: Ghalia Indonesia. (2005). Teori Ekonomi Mikro. Jakarta: MWM. 
. (2009). Economics - Pengantar Mikro dan Makro. Jakarta: MWM.

(2010). Faktor Permintaan Non Fungsiona Group Member Terhadap Permintaan. Binus Business Review. Vol.1 No. 2. Jakarta: BINUS University.

Tabachnick, B. G., and Fidel, L. S. (2007). Using Multivariate Statitics. $5^{\text {th }}$ Edition. Bost Pearson Education. 